\title{
Erratum to: Assessment of potential seismic hazard and site effect in Antakya (Hatay Province), SE Turkey
}

\author{
Semir Över • Aydın Büyüksaraç • Özcan Bektas •
}

Ahmet Filazi

Published online: 6 July 2010

(C) Springer-Verlag 2010

\section{Erratum to: Environ Earth Sci}

\section{DOI 10.1007/s12665-010-0525-3}

Unfortunately, the third author's name in the original version of this article was published incorrectly as Özcan Bekta. The correct name is Özcan Bektas.

The online version of the original article can be found under doi:10.1007/s12665-010-0525-3.

S. Över

Department of Geophysical Engineering,

Mustafa Kemal University, 31200 Antakya, Turkey

A. Büyüksaraç $(\square)$

Department of Geophysical Engineering,

Canakkale Onsekiz Mart University,

17020 Canakkale, Turkey

e-mail: absarac@comu.edu.tr

Ö. Bektas

Department of Geophysical Engineering,

Cumhuriyet University, 58140 Sivas, Turkey

\section{A. Filazi}

Department of Civil Engineering,

Mustafa Kemal University,

31200 Antakya, Turkey 